\title{
DOCUMENTS
}

George Garvy

\section{ALBERT EINSTEIN AND THE NOBEL PEACE PRIZE FOR KARL KAUTSKY}

In 1938, Karl Kautsky was nominated for the Nobel Prize for Peace. Professor Albert Einstein refused to support his nomination for reasons stated in a letter to $W$. S. Woytinsky printed below. This note provides the background for the attempt to obtain Einstein's endorsement. Copy of Woytinsky's letter has not been preserved.

The initiative to put forward Kautsky's name did not come from German or Austrian social-democrats. The move was started by Paul Olberg, who knew W. S. Woytinsky from the Berlin Menshevik "Club" to which both belonged during the twenties until forced to emigrate in 1933. That the initiative came from a Menshevik is hardly surprising in view of the high esteem in which Kautsky was held by Russian socialists and of his personal friendship with many of their leaders. Olberg persuaded a leading social-democratic member of the Swedish Rikstag, Richard Lindström, to spearhead the move, and the subsequent developments are recounted in Olberg's contribution to the Kautsky memorial volume. ${ }^{1}$ Olberg's account of the support obtained in the various countries, by no means limited to socialists, does not mention the United States. Presumably Olberg had no personal contacts among the relatively small socialist movement in the United States. He turned to W. S. Woytinsky, whose enterprising and driving personality and acquaintance with a large number of non-socialists and old friendship with Kautsky seemed to promise an energetic and successful campaign in the New World.

In 1938, Woytinsky, who made a name for himself in Germany as a labor economist and statistician, was working for the Social Security Board in Washington. He had met Kautsky in 1920 when the latter was on his way to Tiflis to visit the isolated and flagging socialdemocratic government of Georgia. At that time, Woytinsky had

1 Paul Olberg, "Karl Kautsky als Kandidat für den Nobel-Friedenspreis", in: Ein Leben für den Sozialismus, Erinnerungen an Karl Kautsky (Hannover, 1954). 
joined the Georgian diplomatic mission in Rome after having served as the editor of the party's official newspaper, Bor'ba, in Tiflis. Woytinsky and his wife, who subsequently lived in several countries of Europe, remained close friends of the Kautskys, and the two families corresponded regularly. ${ }^{1}$ The Woytinskys had met Einstein in 1925 at a dinner given by a cousin of Mrs Woytinsky, who was Einstein's landlord and liked to entertain his famous tenant. They met subsequently several times on similar occasions but had not seen each other after emigration from Germany. ${ }^{2}$ Olberg had clearly overestimated Woytinsky's involvement in the political and intellectual life in his last adopted country. Woytinsky tried to enlist the help of the group around the New Leader, and more specifically of S. Levitas, also of Russian extraction and Menshevik background, and of Algernon Lee to obtain signatures of prominent citizens. ${ }^{3}$ The only individual he approached directly was, apparently, Einstein who in 1921 had enthusiastically supported Masaryk's nomination for the same prize. ${ }^{4}$

Einstein's refusal was entirely in tune with his pacifist convictions and activities which began soon after the outbreak of World War I. "Das Werk über die Kriegsdokumente", to which the letter alludes, and the preparation of which Kautsky had initiated during his short (and only) period of holding a political office (November-December 1918) as the undersecretary (beigeordneter Sekretär) for Foreign Affairs in the Socialist coalition government formed immediately after the Revolution, was, indeed, an incomplete record, hastely compied and released. ${ }^{5}$ The hardly veiled accusations in the letter are easily traced to the burst of Einstein's political activity at the very time when he had become a world-famous scientist. In the words of his most recent biographer, "Scientific renown came just as events in Germany and elsewhere pushed him into a political activity for which he had little

\footnotetext{
1 Among other omissions involving his connection with the social-democratic movement after the Georgian episode, Woytinsky had chosen not to mention this long friendship in his autobiography in which Kautsky's name is not even mentioned. See Stormy Passage (New York, 1961). Emma S. Woytinsky describes the circumstances of meeting Kautsky and the subsequent friendship in Two Lives in One (New York, 1965), p. 127.

2 E. S. Woytinsky, op. cit., pp. 110-12.

${ }^{3}$ Letters to Levitas and Lee are in the Internationaal Instituut voor Sociale Geschiedenis.

4 See his letter of January 19, 1921, in Einstein on Peace, ed. by Otto Nathan and Heinz Norden (New York, 1960), p. 41.

5 Auswärtiges Amt, Die Deutschen Documente zum Kriegsausbruch, gesammelt von Karl Kautsky (Berlin, 1919), 4 vols, and what Kautsky characterized as his "comments": Wie der Weltkrieg Entstand: Dargestellt nach dem Aktenmaterial des Deutschen Auswärtigen Amtes (Berlin, 1919). See "Mein Lebenswerk", in: Ein Leben für den Sozialismus, p. 31.
} 
aptitude. He instinctively supported the left-wing movements set free by defeat and became a devoted if muddled supporter of both pacifism and world government which could only be maintained by force. $\mathrm{He}$ revealed his zealous and perhaps ingenuous belief that Germany's good name would be restored if her war crimes were publicly investigated and, if necessary, admitted."1 Indeed, Einstein had formed with five like-minded individuals a private commission to investigate German war crimes ("with the purpose of thoroughly examining those charges concerning Germany's conduct in the war which have become known abroad and are considered as proved"), which came to nothing. ${ }^{2}$ The tribulations of that first post-revolution year (when Kautsky was busy compiling war documents) must have left a deep feeling of disappointment with the meager support which he received even from the social-democrats who, like Kautsky, had opposed the war. Since his first contact with Friedrich Ebert, the head of the government with whom he had intervened on behalf of the students of the University of Berlin two days after the overthrow of the Kaiser's government, Einstein was always more inclined to see the weaknesses of the Weimar Republic and of its main supporters, the social-democrats, than to support its struggles.

Dr. Wladimir Woytinsky

Nassau Point, Peconic L.I. den 27. Juni 1938

4943 Butterworth Pl. N.W.

Washington D.C.

Sehr geehrter Herr Woytinsky:

Ich würde sehr gerne Ihren Wunsch erfüllen, wenn ich mich hierzu für berechtigt hielte. So aber muss ich bekennen, dass ich Kautsky's Verdienste um die Lösung des Problems der internationalen Sicherheit nicht kenne. Die von Ihnen angeführten Fakten andererseits entbehren jeder Aktualität. Auch ist mir bekannt, dass das Werk über die Kriegsdokumente von sehr zweifelhaftem Wahrheitswert gewesen ist. Es ist mir auch nicht bekannt geworden, dass Kautsky irgendetwas unternommen hat, um die Wahrheit über die in Belgien verübten

${ }^{1}$ Ronald W. Clark, Einstein: The Life and Times (New York and Cleveland, 1970).

2 For Einstein's subsequent involvement with pacifist and similar committees, commissions and congresses, see the item quoted above, p. 108, note 4 . 
Untaten dem deutschen Publikum zur Kenntnis zu bringen. (Auch Schücking hat in dieser Sache völlig versagt). Alles zusammengenommen, kann ich nicht sehen, dass Kautsky den Friedens-Nobelpreis wirklich verdient hätte oder dass die Verleihung desselben an ihn von politischem Wert für die Lösung des Friedensproblems sein würde.

Freundlich grüsst Sie

Ihr

A. Einstein 